\title{
水蒸发驱动柔性自支撑复合发电碳膜
}

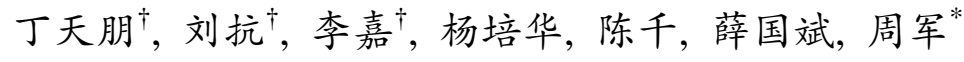 \\ 华中科技大学武汉光电国家研究中心, 武汉 430074 \\ $\dagger$ 同等贡献 \\ * 联系人, E-mail: jun.zhou@ mail.hust.edu.cn
}

2018-07-06 收稿, 2018-08-10 修回, 2018-08-13 接受, 2018-09-04 网络版发表

国家自然科学基金(51672097, 51606082, 51322210, 61434001)和中国博士后科学基金(2015M570639, 2017M610471)资助

\begin{abstract}
摘要利用自然界中无处不在的蒸发作用, 收集利用环境中总量巨大的低品位热能是一种新型可持续能源技 术. 本文制备了一种可直接通过蒸发驱动流动的方式将环境热能转化为电能的柔性自支撑复合碳膜. 该复合碳膜 由碳颗粒和玻璃纤维组成，具有类似钢筋混凝土结构，因而有良好的柔性和抗拉伸性能。一片尺寸为 $1 \mathrm{~cm} \times 4.5$ $\mathrm{cm} \times 0.13 \mathrm{~mm}$ 的复合碳膜最高可获得 $1 \mathrm{~V}$ 的开路电压和 $~ 0.86 \mu \mathrm{A}$ 的短路电流. 通过放大面积, 最高可得到单个器件 $\sim 1 \mathrm{~V}$ 的开路电压和 $28 \mu \mathrm{A}$ 的输出电流. 复合碳膜的这些性质显示了其作为一种新型的可收集环境能源材料, 在绿 色可持续能源利用方面的应用前景.
\end{abstract}

关键词蒸发, 毛细流动, 能量收集, 柔性, 复合碳膜

收集环境中存在的各种微能源(包括机械能、热 能、化学能), 并将其转化为电能是一种极具潜力的 绿色可持续发展能源技术 ${ }^{[1]}$. 近年来, 先进微纳制造 技术的发展为新型环境能源转化提供了新的机遇, 产 生了多种环境能源收集技术, 如压电发电机 ${ }^{[2 \sim 5]}$ 、摩擦 发电机 ${ }^{[6 ~ 8]}$ 、驻极体发电机 ${ }^{[9,10]}$ 、浓差电池 ${ }^{[11]}$ 、渗透 能量转换 ${ }^{[12 ~ 15]}$ 和湿气发电 ${ }^{[16 ~ 18]}$ 等. 环境中的热能无 处不在, 且总量巨大, 但由于其品位较低, 收集利用 十分困难. 如何直接利用环境中的低品位热能进行 发电的工作鲜有报道.

自然界中广泛存在的蒸发现象是一种利用环境 热能将水从液态变成气态的基本现象 ${ }^{[19]}$. 最近, 我 们证明蒸发过程在一片纳米多孔碳膜上可以作为稳 定的驱动力源驱动水流动发电, 从而将无处不在的 环境热能转化成一种可用的新型能源 ${ }^{[20,21]}$. 基于多 孔碳膜的水蒸发流动发电器件在自然环境条件下, 可产生 $1 \mathrm{~V}$ 的稳定开路电压, 并且经过 $100 \mathrm{~h}$ 电压几乎
没有衰减 ${ }^{[20,21]}$. 蒸发发电广泛存在于多种碳材料系 统(包括碳纳米管、乙炔碳黑、甲苯碳黑、戊醇碳黑), 是一种普适现象 ${ }^{[20]}$. 在我们的前期工作中，火焰法 和印刷法制备的碳膜都需要刚性基底(玻璃载玻片或 氧化铝陶瓷片)支撑，该结构限制了碳膜的应用场合， 以及碳膜自身尺寸(比如厚度)的调控能力.

本文设计了一种由碳纳米颗粒和玻璃纤维 (carbon nanoparticles/glass fiber, CNGF)组成的自支 撑复合碳膜, 并将其用于蒸发诱导水流发电. CNGF 复合碳膜与此前报道的发电碳膜相比, 具有如下优 点：(1) 完全自支撑，不需要基底，更便于实际应用; (2) 具有良好的机械稳定性. 类钢筋混凝土结构使得 CNGF复合碳膜具有良好的柔性和抗拉伸性能; (3) 更高的单位面积输出功率. CNGF复合碳膜稳定的机 械结构, 使得我们可以将碳膜的厚度设计得更厚, 从 而获得更大的水蒸发面积和更大的横截面水流量; 而且水可以从碳膜的两面同时蒸发, 进一步增大蒸 
发面积和流量. 最终, 水蒸发驱动柔性复合碳膜在环 境条件下可稳定输出开路电压 $0.93 \mathrm{~V}$, 单个器件输 出电流达到 $28 \mu \mathrm{A}$.

\section{1 材料制备}

CNGF复合碳膜的具体制备过程如下：(1) 将松 节油透醇、乙基纤维素、火焰法制备的甲苯碳黑 ${ }^{[22]}$ 和玻璃纤维按照一定的比例在无水乙醇中加热搅拌, 获得均匀的浆料; (2) 采用印刷的方法将配好的浆料 按照一定的尺寸涂覆在氧化铝陶瓷基底上面; (3) 将 涂有浆料的陶瓷基底放人马弗炉中，在 $370^{\circ} \mathrm{C}$ 的空气 氛围下退火 $150 \mathrm{~min}$, 自然冷却至室温; (4) 将退火后 的碳膜从陶瓷基底上揭下来(图 $1(\mathrm{a})$ ), 获得了如图 1(b)所示的柔性自支撑复合碳膜. 扫描电子显微镜 (SEM)表征结果(图1(c) (e)和S1)表明, CNGF复合碳 膜由玻璃纤维和粒径约 $80 \mathrm{~nm}$ 的碳纳米颗粒组成, 膜 厚约 $130 \mu \mathrm{m}$ (图S2). 微米级的玻璃纤维交错穿插于 碳纳米颗粒之间, 形成类似于钢筋混凝土结构, 这种 结构极大地提高了碳膜的机械性能, 包括弯曲性能 和拉伸性能. 复合碳膜的机械性能和导电性, 都与碳 黑和玻璃纤维比例有关. 如图1(f)所示，随着玻璃纤 维(glass microfiber, GMF)和碳纳米颗粒(carbon nanoparticles, CNP)的质量比从 0.15 提高到 0.6 , 尺寸为 1 $\mathrm{cm} \times 4.5 \mathrm{~cm} \times 0.13 \mathrm{~mm}$ 的复合碳膜能承受的最大拉应力 从 $0.4 \mathrm{MPa}$ 提高至 $4.9 \mathrm{MPa}$. 但是, 当 GMF/CNP比例 达到1.2时, 最大拉应力反而降至1.6 MPa. 由此可见,
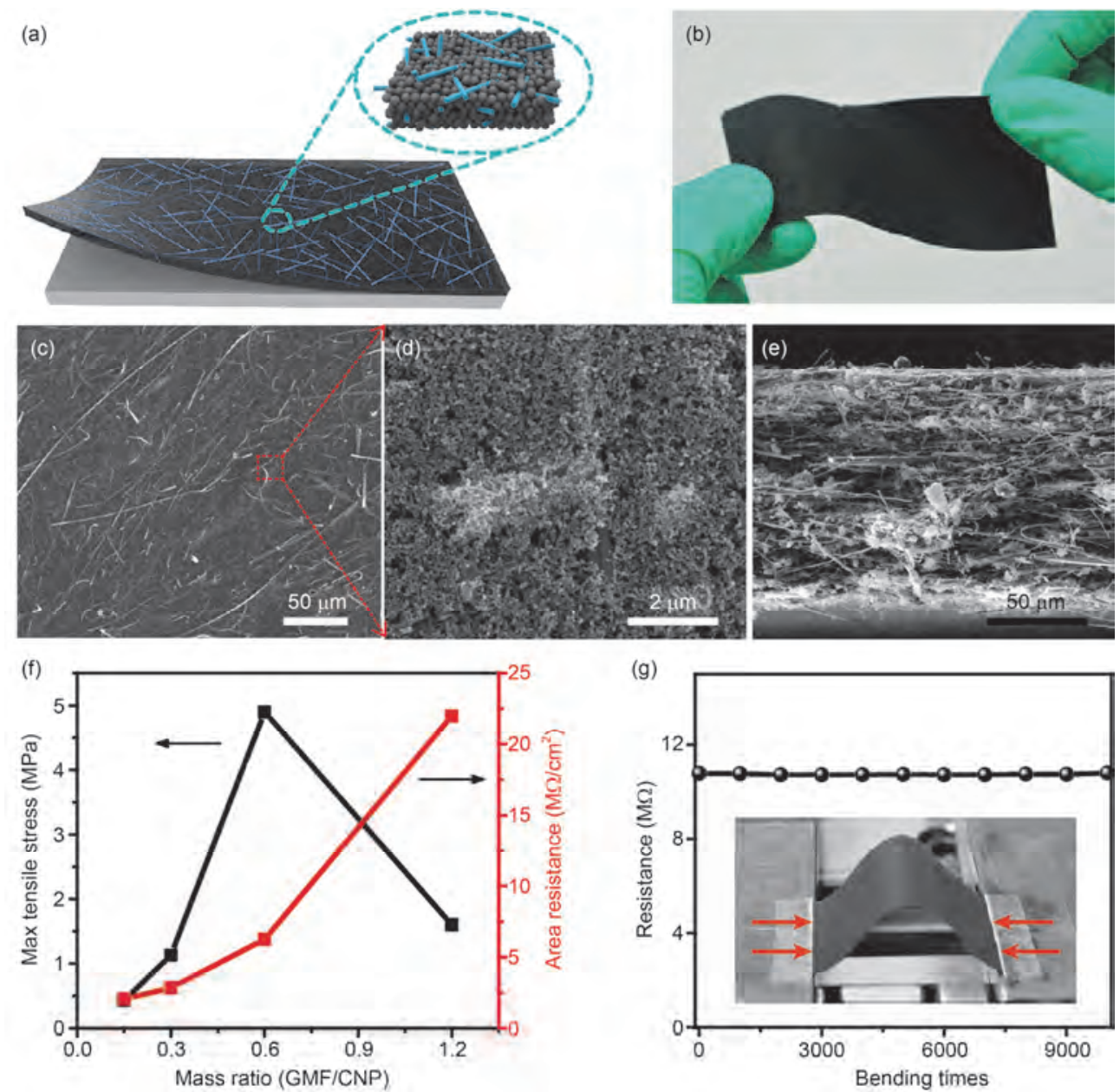

图 1 (网络版彩色)CNGF复合碳膜的基本结构性质. (a) 结构示意图. (b) 光学图片. SEM俯视图(c), 高分辨图(d)和截面图(e). (f) 复合碳膜能承 受的最大拉应力、电阻与 GMF/CNP比例的关系. (g) 弯曲测试

Figure 1 (Color online) Structure and characterization of the CNGF film. (a) Schematic of the free-standing CNGF carbon film. (b) Optical photograph of the carbon film. (c) SEM image of the carbon film in top view. (d) Magnified SEM image. (e) SEM image of the cross-sectional view. (f) Dependence of tensile property and area resistances on the mass ratio of GMF to CNP. (g) Bending test of the free-standing film 
复合碳膜在机械性能上存在一个最优 GMF/CNP比 例, 大约在质量比 0.6 附近. 复合碳膜的电阻随着玻 璃纤维含量的增加而增加, 且不随膜的弯曲而改变. 如图 1(g) 所示, $\mathrm{CNGF}$ 复合膜 $(\mathrm{GMF} / \mathrm{CNP}=0.6)$ 在经过 10000 次 $90^{\circ}$ 弯曲后, 其电阻基本没有变化.

\section{2 水蒸发驱动流动发电性能}

根据机械性能和电阻测试结果, 我们选择机械 性能和电阻合适、纤维碳黑质量比为 0.6 的 CNGF复合 碳膜 $(\mathrm{GMF} / \mathrm{CNP}=0.6)$ 进行后续的发电性能测试. CNGF复合碳膜的上下两端分别用涂覆碳纳米管墨 水的方式负载一层 $5 \mathrm{~mm}$ 宽的碳纳米管层作为电极, 碳纳米管电极与漆包线连接, 连接处用环氧树脂密 封. 将制备好的器件一端置于去离子水中时(图 2(a)), 纳米多孔碳膜内部毛细力会驱动水沿着碳颗粒之间 的微通道从下往上传输. 碳膜上水分的不断蒸发, 形 成碳膜内部源源不断的水流动. 由于微通道的尺寸 较小, 通道壁面处形成的双电层互相重叠. 碳颗粒
Zeta电位约-33.2 mV, 因而通道壁带负电, 整个通道 排斥带同种电荷的阴离子 $\left(\mathrm{OH}^{-}\right)$, 而优先通过带异种 电荷的阳离子 $\left(\mathrm{H}^{+}\right)$. 碳膜内部由蒸发导致的水流动便 会造成带正电荷的离子从底部向上端的定向运动, 形成了动电电流和电压 ${ }^{[23 ~ 26]}$, 实现环境能量的收集 和转换. 图 2(a)显示了尺寸为 $1 \mathrm{~cm} \times 4.5 \mathrm{~cm} \times 0.13 \mathrm{~mm}$ 的复合碳膜在环境条件下的电压输出曲线. 在环境 相对湿度 RH 50\%, 温度 $25^{\circ} \mathrm{C}$ 条件下 (图S3), 器件开 路电压达到 $0.93 \mathrm{~V}$, 并且可持续保持长达 $10 \mathrm{~h}$ 基本 没有变化. 短路电流达到 $0.86 \mu \mathrm{A}$ (图2(b)和 $\mathrm{S} 4$ ), 该 电流大小是火焰法制备的纯碳膜器件的 5 倍以上 ${ }^{[20]}$. 造成电流增加的原因主要有 2 个: (1) CNGF复合膜的 厚度远超过纯碳黑膜, 因而在单片碳膜上可以实现 更大的水流量；(2) CNGF碳膜的正反两面都可以进 行水分蒸发, 因此CNGF碳膜中水的流速以及流量都 得到了提高.

图2(c)为测试装置被密封时器件的输出电压. 从 图中可以看到，实验装置被完全密封后，碳复合膜上
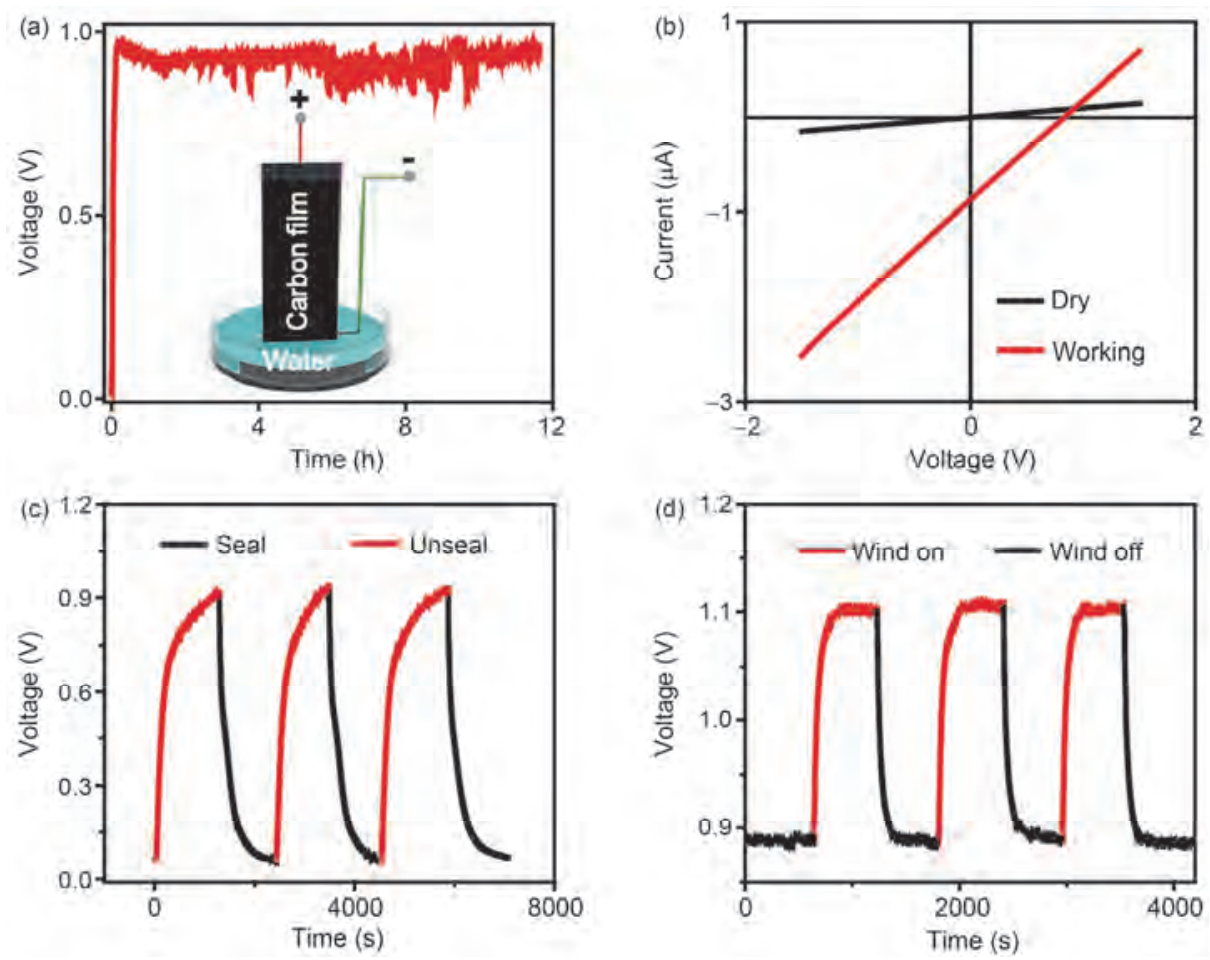

图 2 (网络版彩色) CNGF复合碳膜的发电性能. (a) 开路电压测试曲线及实验装置示意图; (b) 器件干燥时和工作时被水部分浸润状态下的 $I-V$ 曲线; (c) 测试装置被周期性密封时器件的输出电压; (d) 周期性的吹风对开路电压的影响, 风速 $0.15 \mathrm{~m} / \mathrm{s}$

Figure 2 (Color online) Electricity generation performance of the CNGF film. (a) Long lasting open-circuit voltage of a chosen device with carbon film. The inset is the experiment setup. (b) The current-voltage curves of the device at original dry state and working state. (c) Measured open-circuit voltage when the device is periodically sealed and unsealed by a beaker. (d) Open-circuit voltage variation when the devices under periodic blowing with the wind velocity of $0.15 \mathrm{~m} / \mathrm{s}$ 
的水分蒸发逐渐减弱, 直至完全不蒸发, 器件的开路 电压也从 $0.93 \mathrm{~V}$ 逐渐降低, 并最终接近 $0 \mathrm{~V}$. 而当实 验装置解密封后, 输出电压会随着蒸发的恢复逐渐 恢复至原来的大小. 由此可见, 蒸发是整个发电过程 的驱动力源, 增强蒸发过程可以进一步提高器件输 出. 如图 2(d)所示, 当器件被置于 $0.15 \mathrm{~m} / \mathrm{s}$ 的风吹下, 碳膜表面水分的蒸发速率便会加快, 器件的开路电 压也从 $0.89 \mathrm{~V}$ 上升到 $1.1 \mathrm{~V}$; 而当风吹停止时, 器 件的开路电压便会从 1.1 V回复到初始无风时的 $\sim 0.89 \mathrm{~V}$. 对于密封测试和吹风测试, 器件的开路电 压均表现出很好的稳定性和可重复性.

复合碳膜采用印刷的方式制备, 因此可以比较 容易地制备大面积器件, 从而提高电能输出. 如图 3(a)所示, 随着碳膜宽度的增加, 器件的开路电压保 持 $0.93 \mathrm{~V}$ 基本不变, 短路电流随着宽度的增加呈线 性增加, 因此我们可以通过增大碳膜的宽度来获得 高的电流输出, 从而提高整体功率输出. 实验中, 我 们制备了最大宽度为 $40 \mathrm{~cm}$ 的复合碳膜, 整个器件的 短路电流达到 $28 \mu \mathrm{A}$; 而且由于复合碳膜自身具有优 异的柔性, 一片 $4.5 \mathrm{~cm} \times 40 \mathrm{~cm}$ 的复合碳膜可以卷成半 径为 $2.5 \mathrm{~cm}$ 的圆柱体. 增加器件的输出电流及输出功率 的同时, 还可以保证小的整体占用体积. 如图3(b)所示, 复合碳膜卷起来后(保持层间适当间隙), 器件在环境条 件下的短路电流仍为 $28 \mu \mathrm{A}$, 开路电压为 $\sim \mathrm{V}$, 这样 的输出功率已经足以驱动一些小型电子设备.

为了进一步展示 $\mathrm{CNGF}$ 发电复合碳膜在应用方 面的潜力, 我们用发电复合膜在环境条件下产生的 电实现了亚甲基蓝溶液 (methylene blue, MB)的电降
解. 具体实验装置如图4(a)插图所示：首先将 2 个卷 叠发电复合膜器件 (尺寸为 $4.5 \mathrm{~cm} \times 40 \mathrm{~cm}$, 直径 2.5 $\mathrm{cm}$ ) 串联在一起, 获得了 1.6 V 的开路电压和 $23 \mu \mathrm{A}$ 的短路电流(图S5). 两片铂片分别与串联器件的正负 极相连后作为电降解的阳极和阴极, 插在 $7.5 \mathrm{~mL}$ 的 亚甲基蓝溶液中(浓度为 $4.5 \mathrm{mg} / \mathrm{L}$ ). 如图 $4(\mathrm{a}$ )所示, 在 进行电降解时, 阴极和阳极两端的工作电压为 1.3 $\mathrm{V}$, 通过 2 个电极的电流为 $\sim 6 \mu \mathrm{A}$. 为了测试亚甲基蓝 的降解速率，每隔 $6 \mathrm{~h}$ 对亚甲基蓝溶液进行一次紫外 吸收光谱测试(图4(b)), 选取664.5 nm处的吸收峰作 为电降解程度的指示峰. 随着时间的推移, 特征峰的 吸收强度出现明显的降低，在30 h内达到 $96 \%$ 。电解 前后的光学照片也显示, 经过电解之后, 亚甲基蓝溶 液明显变得透明. 由此可见, CNGF发电复合碳膜在 环境条件下，可以自发收集环境热能发电，产生的电 可 以有效地实现亚甲基蓝溶液的降解，显示了其 应用潜力。

\section{3 结论}

本文利用碳颗粒和玻璃纤维，制备了一种可用 于蒸发驱动流动发电的柔性自支撑复合碳膜. 该复 合碳膜具有类似钢筋混凝土结构，因而具有良好的 柔性和抗拉伸性能. 同时与此前报道的发电碳膜相 比, CNGF发电复合碳膜具有更高的电能输出, 一片 尺寸为 $1 \mathrm{~cm} \times 4.5 \mathrm{~cm} \times 0.13 \mathrm{~mm}$ 的器件最高可获得 $1 \mathrm{~V}$ 的开路电压和 $~ 0.86 \mu \mathrm{A}$ 的短路电流. CNGF复合碳膜 易于制备大面积器件, 通过扩大面积获得了单个器 件 1 $\mathrm{V}$ 的开路电压和 $28 \mu \mathrm{A}$ 的输出电流. 该器件
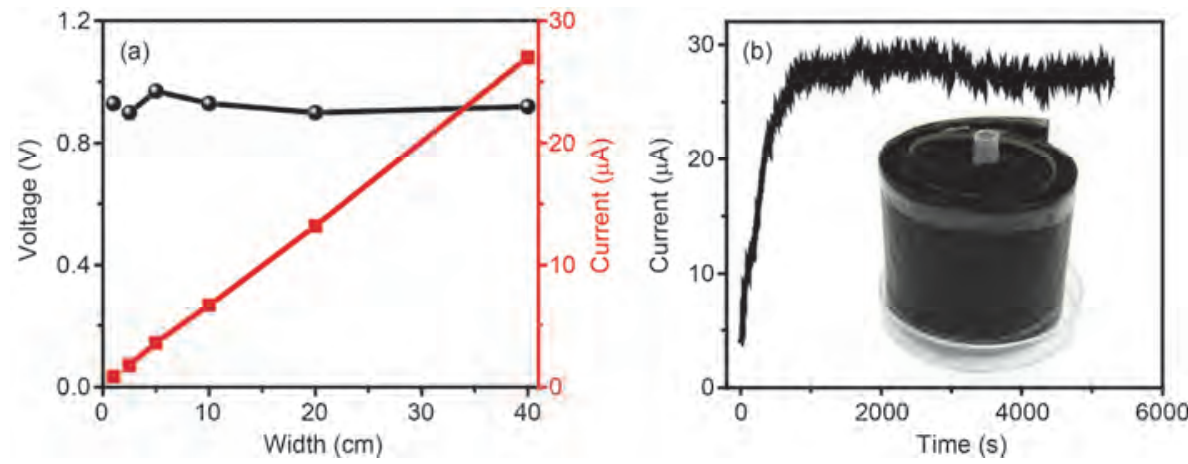

图 3 (网络版彩色) 大尺寸CNGF复合碳膜的发电性能. (a) 碳膜输出的开路电压和短路电流与碳膜宽度的关系. 实验中碳膜的高度固定为 $4.5 \mathrm{~cm}$, 厚度固定为 $130 \mu \mathrm{m}$; (b) 宽度为 $40 \mathrm{~cm}$ 的复合碳膜卷起来时的短路电流输出. 插图为器件的光学照片

Figure 3 (Color online) Scaling up of the device. (a) Dependance of open-circuit voltage and short-circuit current on the widths of the device with a fixed height of $4.5 \mathrm{~cm}$ and thickness of $130 \mu \mathrm{m}$. (b) Short-circuit current variation of a rolled-up device after being fully infiltrated. Inset shows the photo of the device 

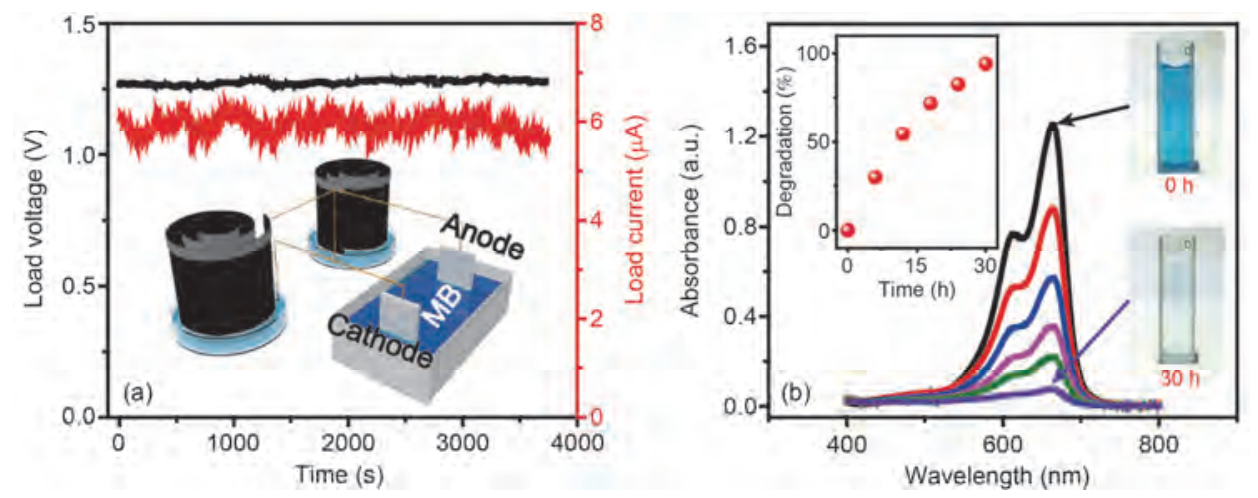

图 4 (网络版彩色)卷叠器件用于亚甲基蓝电降解. (a) 降解过程中阴极和阳极之间的电压以及通过 2 个电极的电流, 插图为实验装置图; (b) 不同降解时间后亚甲基蓝溶液的紫外吸收光谱(取样时间间隔 $6 \mathrm{~h}$ ), 左上插图为亚甲基蓝的降解率随时间的变化关系, 右插图为降解前后亚甲 基蓝溶液的光学照片

Figure 4 (Color online) Demonstraion of MB electrodegradation with two rolled-up devices as power souce. (a) Load voltage and current across the cathode and anode. Inset shows the schematic of the experimental setup. (b) Absorption spectra of the MB solution at different processing time (with time intervals of $6 \mathrm{~h}$ ). The left inset shows the degradation percentage versus the electrodegradation time. The right insets are the optical images of MB solution before and after $30 \mathrm{~h}$ electrodegradation

产生的电可直接电解浓度为 $4.5 \mathrm{mg} / \mathrm{L}$ 的亚甲基蓝溶

液. CNGF复合碳膜优异的机械性能和蒸发发电性能

显示了其作为一种新型的环境能源收集技术的应用 前景.

\section{参考文献}

1 Wang Z L. Self-powered nanosensors and nanosystems. Adv Mater, 2012, 24: 280-285

2 Wang Z L, Song J. Piezoelectric nanogenerators based on zinc oxide nanowire arrays. Science, 2006, 312: 242-246

3 Wang X, Song J, Liu J, et al. Direct-current nanogenerator driven by ultrasonic waves. Science, 2007, 316: 102-105

4 Qin Y, Wang X, Wang Z L. Microfibre-nanowire hybrid structure for energy scavenging. Nature, 2008, 451: 809

5 Xu S, Qin Y, Xu C, et al. Self-powered nanowire devices. Nat Nanotechnol, 2010, 5: 366-373

6 Fan F R, Tian Z Q, Wang Z L. Flexible triboelectric generator. Nano Energy, 2012, 1: 328-334

7 Li A, Zi Y, Guo H, et al. Triboelectric nanogenerators for sensitive nano-coulomb molecular mass spectrometry. Nat Nanotechnol, 2017, 12: 481-487

8 Chen J, Wang Z L. Reviving vibration energy harvesting and self-powered sensing by a triboelectric nanogenerator. Joule, 2017, 1: 480

9 Zhong Q, Zhong J, Hu B, et al. A paper-based nanogenerator as a power source and active sensor. Energy Environ Sci, 2013, 6: $1779-1784$

10 Zhong J, Zhong Q, Chen G, et al. Surface charge self-recovering electret film for wearable energy conversion in a harsh environment. Energy Environ Sci, 2016, 9: 3085-3091

11 Yan Y, Timonen J V, Grzybowski B A. A long-lasting concentration cell based on a magnetic electrolyte. Nat Nanotechnol, 2014, 9: 901-906

12 Cheng H, Zhou Y, Feng Y, et al. Electrokinetic energy conversion in self-assembled 2D nanofluidic channels with janus nanobuilding blocks. Adv Mater, 2017, 29: 1700177

13 Feng J, Graf M, Liu K, et al. Single-layer $\mathrm{MoS}_{2}$ nanopores as nanopower generators. Nature, 2016, 536: 197

14 Ji J, Kang Q, Zhou Y, et al. Osmotic power generation with positively and negatively charged 2D nanofluidic membrane pairs. Adv Funct Mater, 2017, 27: 1603623

15 Yang P, Liu K, Chen Q, et al. Solar-driven simultaneous steam production and electricity generation from salinity. Energy Environ Sci, 2017, 10: 1923-1927

16 Liu K, Yang P, Li S, et al. Induced potential in porous carbon films through water vapor absorption. Angew Chem Int Ed, 2016, 55: 
8003-8007

17 Zhao F, Liang Y, Cheng H, et al. Highly efficient moisture-enabled electricity generation from graphene oxide frameworks. Energy Environ Sci, 2016, 9: 912-916

18 Chen X, Goodnight D, Gao Z, et al. Scaling up nanoscale water-driven energy conversion into evaporation-driven engines and generators. Nat Commun, 2015, 6: 7346

19 Cavusoglu A H, Chen X, Gentine P, et al. Potential for natural evaporation as a reliable renewable energy resource. Nat Commun, 2017, 8: 617

20 Xue G, Xu Y, Ding T, et al. Water-evaporation-induced electricity with nanostructured carbon materials. Nat Nanotechnol, 2017, 12: $317-321$

21 Ding T, Liu K, Li J, et al. All-printed porous carbon film for electricity generation from evaporation-driven water flow. Adv Funct Mater, 2017, 27: 1700551

22 Yuan L, Tao Y, Chen J, et al. Carbon nanoparticles on carbon fabric for flexible and high-performance field emitters. Adv Funct Mater, 2011, 21: 2150-2154

23 Yang J, Lu F, Kostiuk L W, et al. Electrokinetic microchannel battery by means of electrokinetic and microfluidic phenomena. J Micromech Microeng, 2003, 13: 963-970

24 van der Heyden F H, Bonthuis D J, Stein D, et al. Power generation by pressure-driven transport of ions in nanofluidic channels. Nano Lett, 2007, 7: 1022-1025

25 Zhang R, Wang S, Yeh M H, et al. A streaming potential/current-based microfluidic direct current generator for self-powered nanosystems. Adv Mater, 2015, 27: 6482-6487

26 Xu Y, Chen P, Zhang J, et al. A one-dimensional fluidic nanogenerator with a high power conversion efficiency. Angew Chem Int Ed, 2017, 56: 12940-12945 
Summary for “水蒸发驱动柔性自支撑复合发电碳膜”

\title{
Evaporation induced electricity generation in freestanding and flexible carbon-based hybrid film
}

\author{
Tianpeng Ding ${ }^{\dagger}$, Kang Liu ${ }^{\dagger}, \mathrm{Jia} \mathrm{Li}^{\dagger}$, Peihua Yang, Qian Chen, Guobin Xue \& Jun Zhou* \\ Wuhan National Laboratory for Optoelectronics, Huazhong University of Science and Technology, Wuhan 430074, China \\ $\dagger$ These authors contribute equally to this work. \\ * Corresponding author, E-mail: jun.zhou@mail.hust.edu.cn
}

Energy harvesting from ambient environment attracts widespread interest for its great potential in green and sustainable development. Very recently, evaporation, a ubiquitous process existing in nature was demonstrated as a reliable process, which can convert low-grade thermal energy in environment into electricity. Evaporation-driven water flow within a piece of carbon black sheet or printed porous carbon film could generate sustainable direct-current electricity with open-circuit voltage $\left(V_{\mathrm{oc}}\right)$ up to $1 \mathrm{~V}$, and with lifetime over hundreds of hours. However, both the flame-deposited carbon black sheets and all-printed porous carbon films need to be deposited or printed on rigid substrates (e.g., silica glass and $\mathrm{Al}_{2} \mathrm{O}_{3}$ plate) in the previous work, which has deceased the effective evaporation area and occupied excessive space, thus limiting the application of this new energy harvesting strategy as a practical power source.

In this work, we present the fabrication of a flexible and freestanding carbon nanoparticles/glass fiber hybrid film (CNGF) for electricity generation via evaporation-driven water flow within it. The CNGF hybrid film has a structure of reinforced concrete, thus exhibits good flexibility and mechanical properties. The carbon film with the size of $1 \mathrm{~cm} \times 4.5$ $\mathrm{cm} \times 0.13 \mathrm{~mm}$ and glassfiber/carbon nanoparticle mass ratio of 0.6 , has a max tensile stress of 4.9 MPa. The electrical resistance of the carbon film keeps nearly unchanged after 10000 bends at a max bending angle of $90^{\circ}$, indicating its excellent flexibility.

Without the limit of rigid substrates, the double-side evaporation enables higher water flow rate through the film. The freestanding carbon film thus has higher electrical power output than the carbon films reported before. A device with the size of $1 \mathrm{~cm} \times 4.5 \mathrm{~cm} \times 0.13 \mathrm{~mm}$ generates an open-circuit voltage of $\sim 1 \mathrm{~V}$ and current of $\sim 0.86 \mu \mathrm{A}$ under ambient condition. The hybrid carbon film can also be easily scaled-up. We demonstrated a carbon film with the maximum width of 40 $\mathrm{cm}$, which has an output current of $\sim 28 \mu \mathrm{A}$. Furthermore, the excellent flexibility allows the film to be rolled up to save space, even with a high power output.

To demonstrate the application of carbon film, we successfully degraded methylene blue (MB) by using our device as power source. Given the simple fabrication, robust mechanical property, high electricity output, such a freestanding and flexible carbon-based hybrid film shows great potential in environmental energies harvesting for green and sustainable development.

evaporation, capillary flow, energy harvesting, flexible, hybrid-carbon film

doi: 10.1360/N972018-00675 